\title{
ISLAM: MEMBENTUK SAINS DAN TEKNOLOGI
}

\author{
Danusiri \\ Fakultas Ushuluddin Universitas Islam Negeri (UIN) Walisongo \\ Jl. Prof. Dr. Hamka Km 1, Ngaliyan-Semarang \\ e-mail: danusiri@yahoo.com
}

\begin{abstract}
The establishment of science-technology Islam originated from the transcendental consciousness that God acts directly provide instruction to people in his capacity as al-'Alim and al-Mu'allim al-Nās with inspiration pattern into intuition or follow the instructions of the Quran on the basis of faith in the verses relating to science-technology. God teaching techniques outlined by humans with the conceptualization, theorization, saintifikasi, and technologization the verses of Allah either paragraph quraniyyah and kauniyyah. Starting point is the establishment of science-technology read. Results of reading will get something, a concept, or a variable. Thus, the more the reading of a Muslim will increasingly have something, concepts or variables. If the reader can find the basic relationship of two or more things, concepts, variables, then he can find one unit theory. Segususan systematic theory will result in one branch of science. Human intellectual activity that knows no stopping, then starting from only one branch of science will continue to be found various kinds of science. The next route, childbirth science technology. And, science-technology school of Islam embraced the benefits of technology for the service in order to obtain mardatillah.
\end{abstract}

\begin{abstract}
Abstrak: Rute pembentukan sains-teknologi Islam berawal dari kesadaran transendental bahwa Allah berperan langsung memberikan pengajaran kepada manusia dalam kapasitasnya sebagai al-'Alim dan alMu'allim al-nās dengan pola pengilhaman ke dalam intuisi atau mengikuti petunjuk al-Quran atas dasar iman dalam ayat-ayat yang berkaitan dengan sains-teknologi. Teknik pengajaran Allah dijabarkan oleh manusia dengan jalan konseptualisasi, teorisasi, saintifikasi, dan teknologisasi terhadap ayat-ayat Allah baik ayat quraniyyah maupun kauniyyah. Dan, sains-teknologi Islam menganut mazhab manfaat teknologi untuk ibadah dalam rangka memperoleh mardatillah.
\end{abstract}

Keywords: konsep, teori, sains, teknologi, mardatillah. 


\section{A. Pendahuluan}

Al-Quran sebagai sesuatu yang benar berkategori mutlak, tanpa tawar, dan tidak ada keraguan bagi setiap orang Islam atas dasar iman, meminjam istilah Amin Abdullah taken for granted. Dengan demikian, kebenaran Al-Quran tidak perlu diuji, meminjam istilah dari Karl R. Poper, untestable trust. ${ }^{1}$ Kitab suci ini mendeklarasikan bahwa dirinya menjelaskan segala sesuatu. ${ }^{2}$

Bersamaan dengan itu, ia juga menyatakan tidak ada sesuatupun di alam semesta ini yang dialpakan atau terbiarkan berlalu begitu saja ${ }^{3}$, melainkan tetap diurus oleh kitab suci ini. Praksis keurusannya tidak ada yang siasia, dalam arti bermanfaat bagi kehidupan manusia. ${ }^{4}$ Sehubungan dengan ini, Gibb mengatakan "Islam is more a system of theology. It's a complete civilization"5 Senada dengan Gibb, ungkapan berikut menyebutkan bahwa "Istilah 'Islam' dapat digunakan dalam tiga pengertian: awalnya merupakan sebuah agama (identik dengan teologi dalam terminologi sains barat), kemudian menjadi negara dan akhirnya budaya" 6

\footnotetext{
${ }^{1}$ Muslim A.Kadir, Ilmu Islam Terapan, Yogyakarta: Pustaka Pelajar, 2003. h. 5,10

${ }^{2}$ Qs. An-Nahl/16]: 89. Disebutkan dalam ayat ini "wa nazzalnā 'alaikal kitāba tibyānan luklli syai'”'

${ }^{3}$ Qs. Al-An'am /6:38. Disebutkan dalam ayat ini "Ma farrațnā fi al-kitabi min syai'”'

${ }^{4}$ Qs. Ali Imran/3: 191. Disebutkan dalam ayat ini "ma khalaqta haża bațilā"

${ }^{5}$ H.A.R. Gibb, Whither Islam? A Survey of Modern Movement in the Moslem Warld. London:Victor Golanz Ltd, 1932, h.12.

6Phillip K Hitti, History of the Arab. Jakarta: Serambi Ilmu Semesta, 2002, h.181. Konsekuensi logis pernyataan Hitti ini adalah, apa yang disebut negara maupun budaya tidak terlepas dari pangkuan Islam. Praksisnya, negara terjadi karena Islam, demikian juga budaya.
}

Bagian dari 'segala sesuatu' adalah pembentukan sains dan teknologi termasuk bentuk jadinya. Segera dihipotesiskan bahwa sosok sains dan teknologi yang bersumber dari kitab suci ini pasti berbeda dari sains dan teknologi barat yang berwatak sekularisme dan sekaligus ateisme. Secara eksplisit, paradigma sains dan teknologi barat seperti tampak pada aliran: positivisme, positivisme logis, empirisme, realisme, esensialisme, dan objektivisme memang menyatakan nilai sains adalah untuk sains itu sendiri "science for the science", terbebas dari kepercayaan dan nilai-nilai, termasuk nilai keagamaan. ${ }^{7}$ Lebih parah lagi, sains dan teknologi barat, sebagaimana tam-pak pada aliran hedonisme, selalu terkait dengan bisnis kesenangan lahiriah ${ }^{8}$. Pada kesempatan ini dijelaskan bagaimana Islam membentuk sains-teknologi.

\section{B. Rute Pembentukan Sains-Tekno- logi \\ Al-Quran Sebagai Sumber Petunjuk}

Bagi seorang beriman kepada kitab suci Al-Quran, pasti beriman pula bahwa kitab suci ini merupakan sumber petunjuk yang tidak ada keraguan di dalamnya. ${ }^{9}$ Terma petunjuk dalam kitab suci ini secara praktis menggunakan kata 'huda' dan berbagai derivasinya, seperti: hada, ahda, tahdu, tahdi, yahdi, yahdāna, tahtadāna, ihtada, hādin, huda, muhtadān, dan muhtadīn. Keseluruhan terma ini disebut dalam Al-Quran terulang hingga tidak kurang dari 318 kali. Jadi sangat meyakinkan bahwa

\footnotetext{
${ }^{7}$ Hamdani, Filsafat Sains Bandung: Pustaka Setia, 2011, h.153.

8 Ibid., h. 162.

${ }_{9}$ QS. al-Baqarah/2:2.
} 
kitab suci ini menyatakan dirinya sebagai sumber petunjuk. Jika seorang beriman mengikuti petunjuknya akan memperoleh keberuntungan, sebaliknya jika menolaknya justru akan sesat dan memperoleh kerugian, ${ }^{10}$ termasuk dalam pengembangan sains-teknologi. Barat, dalam mengembangkan sainsteknologi tanpa penerangan petunjuk Al-Quran, ternyata gagal memposisikan manusia sebagai pemakmur bumi. Aneka krisis kemanusiaan seperti pola hidup serumah tanpa nikah, revolusi seksualisme, apharteitisme, perlombaan senjata pemusnah massal, dan masih banyak lagi kalau mau disebut, adalah dampak sains-tekionogi barat yang sekularistik-positivistik-ateistik. Oleh karena itu, pengembangan sainsteknologi yang berbasis Al-Quran harus tidak dipandang subjektifistik bagi umat Islam, melainkan dipandang secara objektif bagi pemulihan martabat manusia dari dampak negatif sainsteknologi barat. Penerangan Al-Quran dalam membentuk sains-teknologi sejak pembentukan konsep hingga dimensi aksiologi.

\section{Konseptualisasi (Tașawwur)}

Konsep disebut juga tashawwur adalah gambaran tentang realitas yang ada dalam pikiran ${ }^{11}$, contohnya adalah konsep tentang 'sapi'. Dalam contoh ini pikiran menggambarkan tentang kenyataan 'sapi', dan ini korespon dengan 'sapi' dalam realitas di luar pikiran. Konsep tentang'sapi' dalam pikiran terjadi setelah pemilik pikiran mengobyektifasi 'sapi' dalam realitas di

10 QS. al-A'raf/7:178.

${ }^{11}$ Murtadla Muthahari, Pengantar Menuju Logika, terj. Ibrahim Husein al-Habsyi, Bangil: Yayasan Pesantren Islam, 1994, h. 27-28. luar pikirannya. Pikiran yang di dalamnya memiliki tașawwur tentang 'sapi' menjelma menjadi pengetahuan (knowledge) baginya. ${ }^{12}$ Artinya, sebelum mengobyektifasi pikiran berada dalam kondisi jahl (ketidaktahuan) ${ }^{13}$ tentang sapi.

Dalam paham al-Quran, asal-usul tashawwur bukan semata-mata persepsi indrawi, rasio, atau intuisi sebagaimana paham filsafat ilmu barat, melainkan langsung dari Allah,14 baik melalui ilham-Nya kepada yang Dia kehendaki ${ }^{15}$, manusia dan non manusia-umpama kepada lebah ${ }^{16}$-maupun melalui saluran petunjuknya secara umum, yaitu AlQuran sebagai kodifikasi kalam-Nya. Secara eksplisit Allah mengajarkan kepada Adam-dan keturunanya-semua konsep tentang segala yang ada, dan yang mungkin ada. ${ }^{17}$ Ayat pertama alQuran yang diterima Rasulullah adalah perintah untuk membaca, Iqra' bismirabbika-llażī khalaq. ${ }^{18}$

\section{Kandungan Term Qara'a}

Keseluruhan Al-Quran yang turun dari hadirat Allah ke bumi diterima oleh Rasulullah secara berangsur-angsur tercatat selama 22 tahun, dua bulan 22 hari dimulai pada malam 17 Ramadan

12Jenis pengetahuan semacam ini disebut a posteriori karena terjadi setelah yang bersangkutan mengalaminya. Surajio, Filsafat Ilmu Jakarta: Bumi Aksara, 2010, h.28.

13Muthahari, Pengantar.

${ }^{14}$ Dalam hal ini, Allah memiliki kapasitas al-'Alim terhadap segala sesuatu QS. AlBaqarah/2:29 dan al-Mu'allim an-nās QS. al'Alaq/96:5.

${ }^{15}$ Semua manusia dilhami oleh Allah yang berupa semacam potensi untuk berbuat baik atau buruk. Lihat QS. al-Syams/91:8.

16 QS. an-Nahl/16:68.

17 QS. al-Baqarah/2:31.

18M.Quraish Shihab, Wawasan Al-Quran Bandung: Mizan, 2007, h. 5 
tahun 41 dari kelahiran Nabi dan berakhir tanggal 9 zulhijjah tahun ke 63 usia beliau atau tahun 10 H. ${ }^{19}$ Kandungan ayatnya mencakup segala aspek kehidupan. ${ }^{20}$ Karena turun secara berangsur-angsur itu, maka wajar kalau sesuatu masalah bisa turun berulangkali menggunakan term yang berlainan tetapi bermakna sama karena tuntutan pemecahan problem yang mengemuka di tengah-tengah masyarakat Rasulullah pada waktu itu. ${ }^{21}$ umpama: kata al-ḥars\{ sinonim dengan kata az-zira'ah yang masing-masingnya di sebut hinnga 14 kali, kata al-Qur'ān sinonim dengan kata al-wahyu dan al-Islām dan masingmasingnya disebut 70 kali, dan kata aljahr sinonim dengan kata al-'alaniyyah yang masing-masingnya disebut 16 kali. Maka wajar kalau term qara'a yang secara praksis diterjemahkan 'membaca' dalam bahasa Indonesia, dan term ini menjadi komrehensi (mafhum) yang denotasinya (ma șadaq) cukup banyak, antara lain:

a. Tala dan berbagai derivasinya seperti yatlu, utlu, yatlāna, yutla, dan tilāwah ${ }^{22}$ dan disebut hingga 63 kali.

b. Nadara ${ }^{23}$ dan berbagai derivasinya, seperti: yanḍuru, yanḍurān,

${ }^{19}$ Hudhari Bik, Tarikh at-Tasyri' al-Islami terj. Mohammad Zuhri /t.t], Rajamurah alQana'ah, 1980, h. 5-6.

${ }^{20}$ QS. al-Nahl/16:89; al-An'am/6:38.

${ }^{21}$ M. Quraish Shihab, Membumikan AlQur'an, Bandung: Mizan, 2009, h. 41.

${ }^{22}$ Ahmad Fuad 'Abd al-Baqi, al-Mu'jam alMufahras li Alfazh al-Qur'ān al-Karīm Indonesia: Maktabah Dahlan, /t.th], hh. 197-198

${ }^{23}$ Kata ini terserap ke dalam bahasa Indonesia menjadi 'nalar' yang secara praksis adalah kegiatan berpikir untuk mencarai jawab sesuatu masalah. Dalam dunia akademis, naḍar menjadi penelitian. yundarān, undur dan disebut hingga 127 kali $^{24}$

c. Fakara dan berbagai derivasinya, seperti: yatafakkarān, tatafakkarā, tatafakkarān, dan tafakkarā terulang hingga $18 \mathrm{kali}^{25}$

d. Fafahamna ${ }^{26}$ yang berakar dari term fahima yang berarti memahamkan, adalah stimulus aktifitas berfikir untuk memperoleh sesuatu konsep atau sesuatu.

e. Term: tafqahān, nafqahu, yafqahu, yafqahān, dan yatafaq-qahā yang berakar dari term faqiha terulang hingga 23 kali. $^{27}$

Masih terdapat term lain yang esensinya terkait dengan kegiatan rasio untuk mempersepsi, mengkognisi, dan mengkonseptualisasi seperti: term 'alima dan berbagai derivasi-nya, ulul alabșār, ulu al-albāb, ulu al-nuha, al-ibrah, dan, berbagai term yang berakar pada term 'aqala dan dabbara.

\section{Aktualisasi Qara'a}

Terminal terakhir dalam beragama adalah perbuatan konkrit, baik dalam level perasaan seperti bergembira ketika mengetahui informasi dari sejumlah ayat Al-Quran tentang betapa nikmatnya hidup di surga, level kepercayaan seperti memper-cayai adanya balasan azab di akhirat kelak sehingga takut untuk berbuat maksiat, level pemikiran seperti berijtihad terhadap sesuatu masalah hukum, maupun level indrawi seperti melaksanakan salat lima kali dalam sehari semalam $^{28}$ dan kegiatan membaca atas

24 'Abd al-Baqi', op cit., h. 876-877

25Ibid.,h. 666-667.

26 QS. al-Anbiyā'/21:79.

27 'Abd al-Baqi', loc cit.

${ }^{28}$ Beragama mencakup tiga terminal, pertama keyakinan dalam hati, kedua 
dasar iman terhadap perintah membaca, yaitu 'iqra'bismi rabbika-llażì khalaq. Dengan demikian, membaca atas dasar model pema-haman ini merupakan perwu-judan iman itu sendiri.

Ketika seseorang melaksanakan perintah membaca, apakah ayat Quraniyyah atau kauniyyah ${ }^{29}$ pasti memperoleh sesuatu, pengetahuan (knowledge/tashdiq), atau konsep (tashawwur), atau variabel, termasuk ketika sang pembaca itu mengatakan "Aku tidak paham terhadap apa yang baru saja aku baca dengan serius". Ketidaktahuannya itu adalah pengetahuan yang baru saja ia peroleh dari kegiatan membaca. Sebelum memba-ca, pasti ia dalam keadaan jahl (ketidaktahuan) terhadap denotasi (ma shadaq) 'ketidaktahuan setelah membaca'.

Dari kegiatan membaca dapat dihipotesiskan "semakin banyak membaca, ia semakin banyak memiliki konsep, pengetahuan, atau variabel. Sebaliknya, tidak mau membaca, tidak akan memiliki apa-apa. Dalam pepatah Jawa dikenal "Bodho longa-longo koyo kebo" (bodoh, tidak mengerti apa-apa seperti kerbau), dan ini menyalahi kodratnya seorang muslim karena Allah mengajarkan segala sesuatu kepada

mengucapkan dengan lisannya, dan terminal terakhir mengekspresikan dengan perbuatan. Lihat: Joachim Wach, The Comparative Study of Religions New York: Columbia UniversityPress, 1925, hh.16-40; asy-Syahrastani, Kitāb al-Milāl wa an-Nihāl Qahirah: an-Nahḍah al-Mishriyyah, 1951, h.111.

${ }^{29}$ Jalaluddin Rahmat, Islam Alternatif. Bandung: Mizan, 1988, h. 19. Disebutkan bahwa dalam Al-Quran tidak kurang dari 750 ayat yang berbicara tentang alam semesta dan dapat menjadi inspirasi saintifik, lihat: Ach Maiumun Syamsuddin, Integrasi Multi Multidimensi\& Sains Jogjakarta: IRCiSoD, 2012. h. 238. manusia. ${ }^{30}$ Watak ilmuwan muslim khususnya dan ini mestinya berlaku bagi setiap muslim, ketika dihadapkan kepada ketidakmengertian suatu problem keilmuan adalah memburu dalam arti tafakkur, tadabbur, ta'aqqul, tafahhum, tafaqquh, ta'allum, dan tanaddur hingga suatu saat apa yang ia sadari tidak mengerti menjadi mengerti. ${ }^{31}$

\section{Etika Membaca}

Untuk menjadi tahu (berpengetahuan) atau berilmu, di dalam Islam bukan hanya didorong oleh rasa kagum (tauma) atas sesuatu, hasrat selalu ingin tahu (all men by nature desire to know), atau karena tertumbuk pada masalah (aporia) baik teoritis atau praktis yang harus ia pecahkan ${ }^{32}$, melainkan juga merupakan kewajiban. Dalam Hal ini Rasulullah bersabda: Thalabul 'ilmi faridatun 'ala kulli muslimin wa muslimatin. ${ }^{33}$ Mafhum mukhalafah kandungan hadis ini menunjukkan bahwa tidak mau membaca dan tidak mau mencari ilmu itu sebenarnya termasuk membangkang, sudah barang tentu dosa. Dengan demikian, masuk ke dalam Islam itu belum cukup hanya mengucapkan credo dua syahadad, melainkan harus ada kesediaan dan

${ }^{30} \mathrm{QS}$. al-Baqarah/2:31. Realisasi pengajaran Allah kepada manusia-menurut pemahaman Iqbal melalui teknik konseptualisasi, lihat: $\mathrm{M}$. Iqbal, The Reconstruction of Religious Thought in Islam, Lahore: Kitab Bhavan, 1981, h.13, hasilnya ia memiliki al-ismu dan al-asma' konsep tunggal dan ketakterhinggaan konsep.

31Tuntunan doa dalam Islam untuk pelacakan menuju kesadaran tentang konsep, variabel, teori, dan ilmu adalah: Rabbī zidnī 'ilmā war zuqnī fahmā.

32 Hamdani, op cit., hh.19-20

${ }^{33}$ Hadis riwayat Ibnu Majah no. 220. Lihat Lidwa Pusaka i-Software - Kitab 9 Imam Hadist. 
realisasinya melakukan perintah membaca.

Karena membaca adalah wajib, tentu ada aturannya yang inherent di dalamnya. Mencari ilmu sebagai realisasi qara'a dengan berbagai macam denotasinya bukan semata-mata tuntutan kompetensi dan profesionalisme, melainkan harus juga disadari sebagai apresisasi atas nama Tuhan. ${ }^{34}$ Membaca dengan motif dan tujuan di luar kesadaran atas nama Tuhan akan memperoleh ancaman yang serius dariNya. Banyak hadis yang menjelaskan ancaman ini, satu diantaranya adalah sebagai berikut:

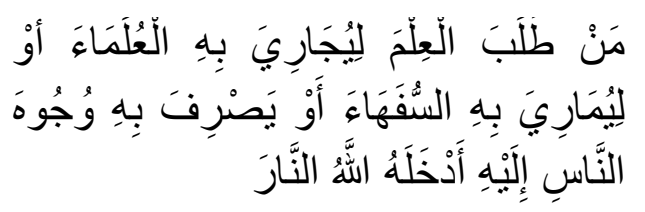

"Barangsiapa menuntut ilmu untuk mendebat para ulama, atau untuk mengolok-olok orang bodoh atau untuk mengalihkan pandangan manusia kepadanya, niscaya Allah akan memasukkannya ke dalam neraka".35

Lebih spesifik lagi, mencari ilmu di luar motif karena Allah akan menempatkan dirinya di neraka, demikian Rasulullah bersabda:

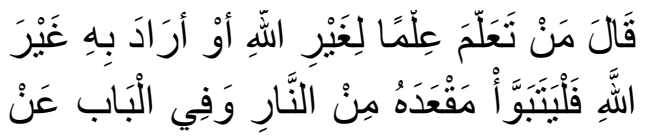

${ }^{34}$ QS. al-'Alaq/96:1

${ }^{35}$ Hadis riwayat at-Tumuzi, hadis, nomor. 2578; Ibnu Majah hadis nomor: 249, 250, 255, dan 256; Ahmad hadis nomor 1564; ad-Darimi hadis nomor: 257, 369, 375, dan 376 - Lihat Lidwa Pusaka i-Software - Kitab 9 Imam Hadist. Hadis nomor 369 ditambahkan lafal yang kandungan artinya "untuk mencari perhatian penguasa'.

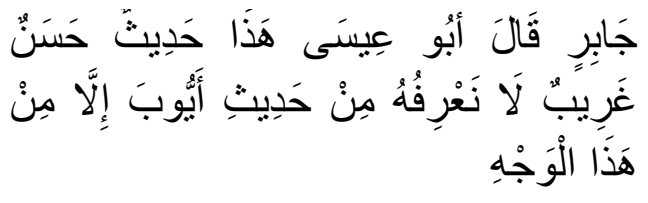

Beliau bersabda: "Barangsiapa belajar Ilmu untuk selain Allah atau menginginkan selain Allah, maka hendaklah dia menempati tempat duduknya (kelak) di neraka". Dan dalam hadits bab ini juga diriwayatkan dari Jabir. Abu Isa berkata; 'Hadits ini hasan gharib, kami tidak mengetahuinya dari hadits Ayyub kecuali dari jalur sanad ini.' 36

Itulah sebabnya, ketika seorang muslim akan belajar, termasuk mempelajari, meneliti, bereksperimen untuk mengerti ${ }^{37}$ Rasulullah memberikan tuntunan doa bahwa 'kemengertian' tentang sesuatu harus bermanfaat secara umum.

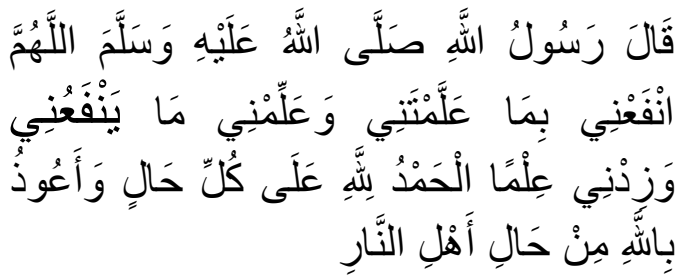

Ya Allah! Berilah manfaat terhadap apa yang telah Engkau berikan kepadaku, ajarkanlah kepadaku sesuatu yang bermanfaat bagiku dan tambahkanlah kepadaku ilmu. Segala puji hanya milik Allah pada semua kondisi (baik kondosi bahagia maupun susah) dan aku berlindung kepada Allah dari perbuatan penduduk neraka."38

Singkatnya, kegiatan keilmuan (pembentukan konsep, teori, ilmu,

36 HR. at-Turmuz\{i, hadis nomor 2579, Lidwa Pusaka i-Software - Kitab 9 Imam Hadist

37 Mencakup konseptualisasi,teorisasi,saintifikasi,dan teknologisasi.

38 Ibid., hadis nomor 3523. 
teknologi, dan aksiologi) dalam Islam merupakan suatu ritual atau ibadah.

\section{Teorisasi dan Saintifikasi}

Teori dapat didefinisikan hubungan dasar dari dua atau lebih sesuatu atau konsep atau variabel. ${ }^{39}$ Sementara itu, yang dimaksud hubungan dasar adalah pola hubungan yang mesti harus terjadi dan tidak ada pola hubungan lain. Contohnya adalah ketika Sumaryono menikah dengan Sumaryani, maka dapat dilakukan teorisasi bahwa akan ada anak yang lahir akibat pernikahan keduanya. Kelahiran anak hanya dimungkinkan kalau Sumaryono berhubungan seksual dengan Sumarya-ni. Hubungan bersebadan yang menjadi sebab bertemunya sel sperma Sumaryono dengan indung telur milik Sumaryani di dalam rahimnya inilah yang dimaksud dengan hubungan dasar. ${ }^{40}$ Jika keduanya tidur berhimpitan tetapi tidak melakukan hubungan seksual Sumaryani tidak akan pernah melahirkan anak. Tidur berhimpitan hanya merupakan hubungan aksiden bagi terwujudnya anak.

${ }^{39}$ Muhammad Nur Ibrahimi, Ilmu Mantiq Surabaya: Salim Bahan, /t.th.], h.3; Bertrand Russel, Human Knowlwdge, Its Scope and Limits Oxford: Oxford University, 1979, h.439.

${ }^{40}$ Teknologi bayi tabung infitro fertilization secara syar'i termasuk hubungan dasar karena mempertemukan sel spermatozoa Sumaryono dengan indung telur ovum Sumaryani dalam tabung medis, di luar tubuh Sumaryani. Setelah berproses kemudian menyatu, menjadi embrio, disuntikkan oleh dokter ahli kandungan yang menanganinya ke dalam rahim Sumaryani. Biasanya dokter menyuntikkan hormon progiesterone pada ibu hamil agar janin bertahan di rahim. Proses panjang selanjutnya janin lahir ke dunia, baik secara alamiah atau operasi caesar; atau mempertemukan spermatozoa dengan indung telur ke dalam tabung medis hingga berproses $100 \%$ di dalam tabung hingga menjadi bayi yang dikeluarkan dari tabung tersebut.
Sains apapun jenisnya, dibedakan dari knowledge, hanya bertumpu pada teori yang diperoleh dari objek pengetahuan yang berupa data-data fakta empiri. Tegasnya, sains adalah kumpulan sistemik dari segugusan teori. ${ }^{41}$ Yang dimaksud kumpulan sistemik harus memenuhi kualifikasi metode ilmiah sebagaimana ungkap Kemeny ${ }^{42}$, atau keteraturan data. ${ }^{43}$

Untuk memperjelas bagaimana sebuah ilmu terbentuk, berikut ini disampaikan sebuah bagan ilmu:

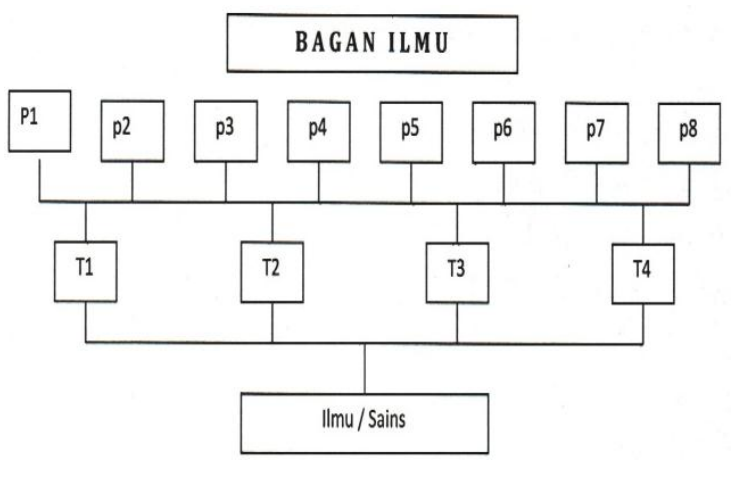

41Hamdani, op cit., h. 151; John Kemeny, $A$ Philosopher looks at Science New York: Van Nostrand Reinhold, 1981, h. 175.

${ }^{42}$ Metode ilmiah mencakup: genetic explanation, intentional explanation, reasioning explanation, dispotitional explanation, functional explanation, explanation through empirical generalazation, dan explanation throught formal theory. Lihat: Hamdani, op cit., h.150.

43Sheldon J.Lachman, The Foundations of Science New York: Vantage Press, 1989, h.13. esensi keteraturan data adalah data serial dan keterkaitan dalam batas ruang lingkup pengamatan. Dapat dicontohkan di sini bahwa teori menyuntik yang tidak menimbulkan rasa sangat sakit dibangun dari sejumlah konsep atau sesuatu atau variabel praksis, jarum suntik yang tajam, steril dari kuman, bakteri, maupun virus, spirtus yang doleskan pada bagian yang akan disuntik, materi yang disuntikkan, penyuntikan yang tepat pada rongga aliran darah, ketegangan posisi bagian tubuh yang akan disuntik, kompetensi prima dari penyuntik, dan kesediaan tulus yang akan disuntik. Dalam kasus menyuntik ini tidak mungkin mengumpulkan data-data tentang gunung dan yang berkaitan dengannya. Data-data tentang gunung tidak serial dengan data-data teknik penyuntikan pasien. 


\section{Keterangan:}

$$
\begin{aligned}
& \mathrm{P}=\text { sesuatu, pengetahuan, konsep, } \\
& \quad \text { variabel. } \\
& \mathrm{T}=\text { teori }
\end{aligned}
$$

\section{Pembidangan Sains}

Sebenarnya, pemisahan dikotomis bahwa ilmu dapat dibedakan menjadi ilmu agama dan ilmu umum, atau trikotomis: ilmu-ilmu kealaman (natural sciencies), ilmu-ilmu sosial (social science), dan humaniora, atau trikhotomi lainnya: ilmu-ilmu normatif (normative sciencies), ilmu-ilmu teoritis (theoritical sciencies), ilmu-ilmu praktis (practical sciencies) yang masing-masing berbeda, terutama sumbernya, menurut ilmu Islam tidak memilki pijakan yang kuat.

Ilmu Islam ${ }^{44}$ mengakui dikotomis, trikotomis, atau multikotomis yang mengerucut menjadi konsursium ilmu. Namun agama ini menyatakan bahwa semua ilmu, apapun jenisnya, berasal dari Allah dalam kapasitas sebagai al'Alim dan al-Mu'allim. Diktum ini bisa mengacu kepada ayat sebagai berikut: "Dia mengajar kepada manusia apa yang tidak diketahuinya." 45

Kata 'ya'lam' pada ayat ini merupakan sighat fi'il mudari' memilki dua macam makna: zaman hal (sekarang) dan zaman istiqbal (waktu yang akan datang).46 Dari pembedaan kedua

${ }^{44}$ Kuntowijoyo menulis sebuah buku berjudul "Islam sebagai Ilmu" dan berisi tiga tema besar: epistemologi, metodologi, dan etika. Salah satu ciri Islam sebagai ilmu adalah objektif, bukan hanya subjektif bagi umat Islam, tetapi semua manusia mengakuinya tanpa menyadari bahwa 'sesuatu' itu berasal dari Islam. Lihat: Kuntowijoyo, Islam Sebagai Ilmu Jakarta: Teraju, 2005, hh. 62-64.

${ }^{45}$ QS. al-'Alaq/96:5.

${ }^{46}$ Anton Dahdah, Mu'jam Qawa'id alLughat al-'Arabiyyah Beirut: Maktabah Lubnan, 1981, h. 114. makna ini, dapat dipahami bahwa pengajaran Allah kepada manusia bukan hanya terbatas pada ketakterhinggaan konsep (zaman hal), saya tahu . . ., melainkan juga 'saya dapat menjadikan ini, ini, dan ini menjadi itu'. Kata 'itu' dalam ungkapan ini pada saat sekarang belum ada wujudnya. Karena kegiatan akal yang senantiasa melakukan konseptualisasi terhadap objek-objek, hasilnya mampu mengubah benda-benda alami menjadi benda-benda budaya, bahkan peradaban. ${ }^{47}$ Singkatnya, pengajaran Allah kepada manusia mencakup bukan saja hanya ilmu-ilmu normatif, melainkan juga ilmu-ilmu teoritis dan ilmuilmu teknik atau ilmu praktis. ${ }^{48}$ Proses konseptualisasi pengetahuan, teori, dan sains dari Allah kepada manusia dapat dilihat pada skema sebagai berikut:

MODEL 149

PROSES TERJADINYA PENGETAHUAN

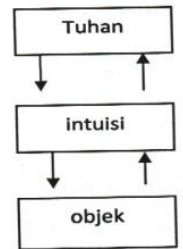

47 Muhammad Iqbal, Stray Reflection Lahore:SH Ghulam Ali\&Sons, 1961, h. 66.

${ }^{48}$ Ciri ilmu praktis atau ilmu teknik adalah baik tujuan maupun objek sama-sama belum ditemukan. Keduanya baru dapat ditemukan ketika suatu ilmu itu teruji dalam dunia empiri. Ilmu teknik otomotif yang merancang satu unit sepeda motor yang penampilannya indah, gesit, irit bahan bakar, dan tangguh, baru bisa dikatakan benar-benar sebagai ilmu yang devinitif ketika sepeda motor itu sudah terwujud kemudian dihidupakn, didemonstrasikan, dikenadarai dalam waktu yang cukup lama dalam jalanan berliku, menanjak dan meturun, jalanan halus maupunn seperti gula kacang, dan terbukti tampilannya memang indah, gesit, tangguh, dan irit bahan bakar jika dibandingkan dengan sepeda motor lain yang sekelas.

${ }^{49}$ Kedua model epistemologis perolehan pengetahuan ini dapat dilihat pada: Danusiri, Epitemologi Dalam Tasawuf Iqbal Yogyakarta: Pustaka Pelajar, 1996, h. 65-66. 


\section{Keterangan}

Yang dimaksud objek dalam skema di atas adalah objek yang bersifat sam'iyyah, secara literal berarti sesuatu yang hanya didengar dan yang dimaksud adalah wahyu yang datang dari Allah sebagai petunjuk dan berada di luar yang dipikirkan oleh manusia, eskatologis yang bersifat immaterial, seperti: surga, al-hauḍ, thuba, neraka, 'arsy, rafraf, sidratul mutaha, mimbar, kursyi, malaikat, syafaat,dan iblis

Objek-objek wilayah ini tidak dapat dipersepsi oleh indera, melainkan diterima atas dasar iman melalui intuisi.

MODEL 2

\section{PROSES TERJADINYA PENGETAHUAN}

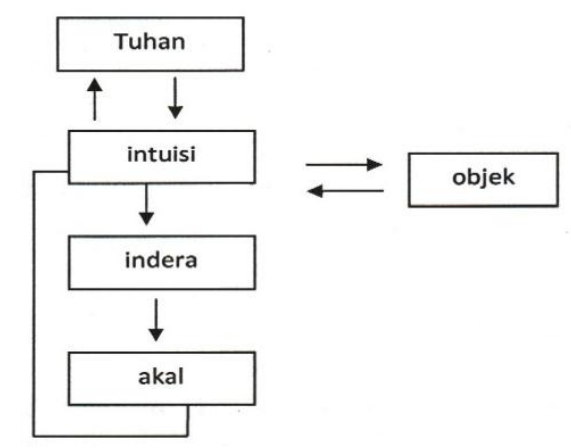

\section{Keterangan}

Konsep, pengetahuan berasal dari Allah. Allah mengilhamkan kepada manusia ke dalam intuisi (qalb/fuad) muatan ilham menembus kepada indra. Data-data indrawi menuju kepada akal. Ada pengolahan di dalamnya hingga menghasilkan suatu pengetahuan.

Skema di atas (model 2) disarikan dari gagasan Iqbal dalam menafsirkan bagaimana Allah melimpahkan pengetahuan, konsep, variabel, dan sains kepada manusia. ${ }^{50}$ Demikian ia berujar:

What is screte of nevelties of science

50 Muhammad Iqbal, Asrar-i-Khudi terj. Reinold Alayne Nicholson, The Scretes of The Self Lahore: Ashraf Press, 1950, h. 14.
A desire wich realised it self by its own strenght

And burst fort from the heart and took shape

Nose, hand, brain, eye, and ear, thought, imagination,

Feeling, memory, and understanding

Intisari dari model pembelajaran Allah kepada manusia. Pertama-tama Allah mengilhamkan sesuatu ke dalam hati sanubari. Kedua, sesuatu membus ke indra, bisa kepada penglihatan saja kalau sesuatu itu hanya penampakan ke dalam indra penglihatan, umpama pemandangan di suatu puncak gunung. Sesuatu bisa hanya menembus ke indra pendengaran saja, umpama gelombang suara. Sesuatu bisa menembus ke indra penglihatan dan pendengaran, umpama menonton tayangan televisi, di dalamnya ada suara dan gambar, dan animasi. Sesuatu bisa menembus ke indra penglihatan dan pencecap, umpama merasakan lezatnya makan nasi dengan lauk gulai kepala ikan. Sesuatu bisa menembus ke indra penglihatan dan penciuman hidung, umpama melihat dan mengisap harumnya bunga melati. Ketiga apa yang diterima indra berlanjut ke akal. Di sini terdapat aktifitas berfikir hingga menimbulkan suatu pengertian. Kualitas enak, baik, indah, banyak, sedikit adalah hasil dari pemaknaan gejala yang masuk ke dalam akal.

Pembidangan sains sebenarnya hanya ditentukan oleh jenis objeknya. Jika objek yang dipersepsi itu adalah benda-benda alamiah, maka sains yang akan terbangun adalah segugusan konsep, proposisi, dan teori pembentuk sains kealaman (natural science). Contoh 
ilmu ini antara lain: teknik sipil dan teknik komputer. Jika objek yang dipersepsi itu ditinjau dari aspek fa'alnya, maka sains yang terbangun adalah segugusan konsep, proposisi, dan teori pembentuk ilmu-ilmu praktis (practical science). Contoh ilmu ini antara lain: teknik otomotif dan teknik elektro. Jika objek yang dipesepsi ditinjau dari aspek kualitas maka ilmu yang akan terbangun adalah sekumpulan konsep, proposisi, dan teori penbentuk ilmu-ilmu normatif. Contoh ilmu normatif antara lain ilmu akhlaq, ilmu fiqh, dan tafsir-hadis. Jika objek yang dipersepsi itu perilaku manusia, maka sains yang akan terbangun adalah sejumlah konsep, proposisi, dan teori pembentuk ilmu-ilmu sosial. Contoh ilmu-ilmu sosial antara lain sosiologi, antropologi, dan psikologi sosial.

\section{Teknologisasi}

Kegiatan intelektual manausia tidak boleh berhenti pada sains, mengerti tentang suseuatu, bahwa air dipanaskan $100^{\circ} \mathrm{C}$ pasti memuai, bahwa permukaan air pada beberapa bejana yang saling terhubung adalah sama, dan natur air mengalir pada tempat yang lebih rendah dari keberadaan semula. Ilmu harus berlanjut dan menghasilkan teknologi. Teknologi memang anak kandung dari sains itu sendiri. ${ }^{51}$

Istilah teknologi berasal dari bahasa Yunani 'technologia'. Kata ini terdiri atas dua konsep,'techne' dan 'logos'. Arti asal 'techne, adalah art, skill, dan science. Secara istilahi berarti seperangkat prinsip, metode rasional yang terkait dalam memproduksi sesuatu. Kata 'logos' secara umum

51 Muslim A Kadir, op cit., h. 34. berarti ilmu atau sains. ${ }^{52}$ Jadi, yang dimaksud dengan teknologi adalah ilmu tentang metode memproduksi sesuatu. Membuat gedung tinggi, kokoh, indah dan megah adalah berdasar pada teknologi - yang secara akademis untuk era mutakhir ini merupakan kolaborasi dari berbagai ilmu teknik, seperti arsitektur, sipil, matematik, dan yang lainnya yang terkait.

Secara empiris, pembuatan gedung tampak tidak terkait dengan doktrin AlQuran, bahwa teknolog pembuat itu sekularis-ateistik atau teistik-islamis adalah sama saja. Akan tetapi, dalam analisis ilmu Islam, kegiatan ini sangat inherent dengan doktrin Al-Quran, yaitu jika ditelusur balik yang bermula dari pembentukan konsep. Dalam setiap langkah rute keilmuan, teknolog Islam senantiasa berkesadaran ilahiyah

\section{Aksiologi Ilmu}

Term aksiologi berasal dari bahasa Yunani 'axios' yang berarti nilai atau manfaat, dan 'logos' yang berarti ilmu. Dengan demikian, secara praktis aksiologi berarti bagaimana memandang, dalam kacamata memandang menurut apa adanya, metode ilmiah, hingga dimensi metafisikanya, bahwa sesuatu itu memilki nilai atau manfaat. ${ }^{53}$

Karena pembentukan sains-teknologi Islam dituntun oleh doktrin alQuran dan basis sang ilmuwan maupun teknolognya adalah kesadaran ilahiyahsebagai perwujudan dimensi metafisik maka dalam merangcang kegunaan harus tetap mengacu atas nama Tuhan, bismi Rabbik'. Gedung kokoh, indah, dan

52 Dagobert D Runes, Dictionary of Philosophy Totowa-New Jersey: LittlefieldAdams\&Co., 1976, h. 314.

53 Runes, op cit., h. 32. 
mewah dapat difungsikan sebagai pusat kegiatan kasino, lokalisasi transaksi seksual, atau secara umum sebagai media kesenangan lahiriah-dunyawiyah (hedonistik). Pemanfaatan model ini didasarkan atas pemihakannya pada 'the rational theory of value', the naturalistic theory of value, atau 'the emotive theory of value terhadap gedung tersebut, bisa juga digunakan sebagai halaqah ulama sedunia dalam aktivitasnya mengupayakan kedamaian dunia dan kemakmuran bumi yang didasarkan pada pemihakan 'the intuitive theory of value ${ }^{54}$ yang wujud konkritnya adalah kesadaran islamiyah. Final goal sainsteknologi Islam adalah marḍatillāh.

\section{Implikasi}

Alur pikir pembentukan sainsteknologi sejak dari konseptualisasi hingga aksiologisasi sepenuhnya dideduksikan pada wahyu, al-Qur'ān dan al-sunnah al-șahịhah, atau minimal hasan, masih dalam kategori hadis yang maqbāl-ma'māl. Implikasi model pemikiran ini berbeda dari model pemikiran unifikasi antara doktrin al-Quran, inklusif di dalamnya al-sunnah alșạịhah sebagaimana dikembangkan oleh akademisi UIN Walisongo Semarang karena sistem kerjanya mengelaborasi antara Islam dan non-Islam, bisa berwujud khasanah keilmuan barat atau khasanah-khasanah lokal.

Senafas dengan unifikasi UIN Walisongo adalah model interkoneksi dari akademikus UIN Sunan Kalijaga, yang bertumpu pada 'sarang laba-laba (spider web)'-nya Amin Abdullah, karena salah satu unsur koneksitas sains- teknologi adalah juga dari unsur nonIslam.

Model 'pohon ilmu' dari akademikus UIN Malang pun berbeda jauh jika diukur dari model deduksi atas wahyu sebagaimana penulis ajukan ini. Gagasan Imam Suprayoga meruapakan cerminan berpikir bebas dan bertolak dari ontologia konsursium ilmu yang secara devinitif menjadi acuan Dikti Kemenag dengan cara mencari pembenaran dari wahyu dari berbagai unsur langkahlangkah keilmuan. Profil sains-teknologi Imam Suprayoga, Amin Abdullah, bahkan juga Naquib al-Attas dan Mahdi Ghoslani yang memprakarsai integrasi agama dan sains hanya mencapai - atas dasar the emotive theory of value - taraf islami karena bangunan gagasan mereka tidak dideduksikan secara langsung dari wahyu. Wallahu a'lamu bi ash-shawāb.

\section{DAFTAR PUSTAKA}

Al-Qur'ān al-Karīm

'Abd al-Baqi, Ahmad Fuad, al-Mu'jam alMufahras li Alfazh al-Qur'ān alKarīm. Indonesia: Maktabah Dahlan, tth.

Bik, Hudlari, Tarikh at-Tasyri' al-Islami (terj.), Mohammad Zuhri. [t.t]: Rajamurah al-Qana'ah, 1980.

Danusiri, Epitemologi Dalam Tasawuf Iqbal. Yogyakarta: Pustaka Pelajar, 1996.

Dahdah, Anton, Mu'jam Qawa'id alLughat al-'Arabiyyah. Beirut: Maktabah Lubnan, 1981.

Gibb, H.A.R, Whither Islam? A Survey of Modern Movement in the Moslem Warld. London:Victor Golanz Ltd., 1932. 
Phillip K Hitti, Phillip, History of the Arab. Jakarta: Serambi Ilmu Semesta, 2002.

Hamdani, Filsafat Sains, Bandung: Pustaka Setia, 2011.

Ibrahimi, Muhammad Nur, Ilmu Mantiq (Surabaya: Salim Bahan, tth.

Iqbal, Muhammad, Asrar-i-Khudi, terj. Reinold Alayne Nicholson, Lahore: SH Ghulam Ali \&S ons, 1950.

Iqbal, Muhammad, The Reconstruction of Religious Thought in Islam, Lahore: Kitab Bhavan, 1981.

John Kemeny, John, A Philosopher looks at Science. New York: Van Nostrand Reinhold, 1981.

Kadir, Muslim A, Ilmu Islam Terapan. Yogyakarta: Pustaka Pelajar, 2003.

Kuntowijoyo, Islam Sebagai Ilmu. Jakarta: Teraju, 2005.

Lachman, Sheldon J., The Foundations of Science. New York: Vantage Press, 1989.

Murtadla Muthahari, Murtadla, terj. Ibrahim Husein al-Habsyi, Pengantar Menuju Logika. Bangil: Yayasan Pesantren Islam, 1994.

Rahmat, Jalauddin, Islam Alternatif. Bandung: Mizan, 1988.

Runes, Dagobert D, Dictionary of Philosophy. Totowa-New Jersey: Littlefield-Adams \& Co., 1976.

Russel, Bertrand, Human Knowlwdge, Its Scope and Limits. Oxford: Oxford University, 1979.

Shihab, M. Quraish, Wawasan Al-Quran. Bandung: Mizan, 2007.

Shihab, M. Quraish, Membumikan AlQur'an, Bandung: Mizan, 2009.

Surajio, Filsafat Ilmu. Jakarta: Bumi Aksara, 2010.

asy-Syahrastani, Abi al-Fath 'Abd alKarīm, Kitāb al-Milāl wa an-Niḥāl,
Qahirah: an-Nahḍah al-Mishriyyah, 1951.

Syamsuddin, Ach Maimun, Integrasi Multi Multidimensi\& Sains. Jogjakarta: IRCiSoD, 2012.

Wach, Joachim, The Comparative Study of Religions. New York: Columbia UniversityPress, 1925.

Lidwa Pusaka i-Software - Kitab 9 Imam Hadist 